\title{
Comparison of the Combined Effect of Intra Row Spacing and Harvesting Interval on Yield and Yield Components of Swiss Chard (Beta vulgaris L.)
}

\author{
Zenebe Woldu* Kemal Negawo Tringo Melak Yared Gebeyaw \\ Wolkite University, P.O.Box 07, www.wku.edu.et, Wolkite, Ethiopia
}

\begin{abstract}
The study was carried out to evaluate the combined effect of intra-row spacing and harvesting interval (frequency) on yield and yield components of Swiss chard (Beta vulgaris L.), variety Ford Hook Giant. The experiment was laid out in a Randomized Complete Block Design (RCBD) with a $3 * 3$ factorial arrangement in three replications. The factor levels were: $25 \mathrm{~cm}, 30 \mathrm{~cm}$ and $35 \mathrm{~cm}$ for intra-row spacing and 6,12 and 18 days for harvesting interval. Statistically significant differences were observed among the treatment combinations on their effects on all parameters evaluated (yield, leaf length, leaf number and plant height) except leaf width. The highest yield $(42.51 \mathrm{t} / \mathrm{ha})$ and yield components $(32.0 \mathrm{~cm}$ average leaf length, 8.17 average leaf number/plant, $17.67 \mathrm{~cm}$ average leaf width and $43.33 \mathrm{~cm}$ average plant height) were obtained from the combined effects of $35 \mathrm{~cm}$ intra-row spacing and 18 days harvesting interval. Conversely, the lowest measurements of the same parameters were recorded from the combined effects of $25 \mathrm{~cm}$ intra-row spacing and 6 days harvesting interval. Growers under Wolkite conditions are therefore recommended to grow Swiss chard in a similar way.
\end{abstract}

Keywords: Swiss chard, intra-row spacing, harvesting interval, yield and yield components.

DOI: $10.7176 / \mathrm{JBAH} / 9-19-06$

Publication date:October $31^{\text {st }} 2019$

\section{Introduction}

Swiss chard (Beta vulgaris L.), which is also sometimes known as spinach beet, sliver beet, seakale beet, chard leaf beet and spinach in various parts of the world, belongs to the family Chenopodaceae (Swiader et al., 1992 and Smith et al., 2001). It is a highly nutritious leafy biennial vegetable crop frequently grown as fore-crop or after-crop in crop rotation system. It is widely known for its year round availability, low cost and wide utilization in many dishes (Gao et al., 2009). Nutritionally, it is important to alleviate widespread nutritional deficiencies since it contains high levels of vitamins (A, B1, B2, B3, B6 and C), minerals ( $\mathrm{Ca}, \mathrm{P}, \mathrm{Fe}, \mathrm{Mg}, \mathrm{Cu}, \mathrm{Zn}, \mathrm{Mn}$ and K), dietary fiber, protein, chlorine, pantothenic acid as well as carbohydrates yielding about $20 \mathrm{kcal}$ per $100 \mathrm{~g}$ (Pyo et al., 2004; van Wyk, 2005; Faber et al., 2007 and George, 2015). Medicinally, it is known to have anti-oxidant values as well as a great role in cardiac health, brain function, cancer fighting, bone health, digestion and eye protection (Smith et al., 2001).

Plant spacing (population density) plays an important role in optimizing the yield of leafy vegetables including Swiss chard. Too high or low plant population density may result in lower yields and quality while improper spacing can cause pest and disease incidence, which again leads to the same problem (Seid et al., 2013, and Lopez et al., 2005). Jenet et al. (2008) also reported that Swiss-chard yield and quality was influenced by different combinations of harvesting intervals and spacing.

Harvesting in Swiss-chard production technology is accomplished by removing the outer matured leaves at specified time intervals over its growing period. As reported by Amango et al. (2006), leaf yield was drastically reduced with continuous harvesting. Aliyu et al. (2002) on the other hand stated that, harvest maturity was one of the major factors that determined the composition and quality of Swiss-chard. The right time of harvesting maturity also resulted in enough amounts of physicochemical composition and antioxidant levels (Kolato et al., 2010).

However, due to limited technical information about its culture, different combination of the two factor levels have been used worldwide depending on the soil and climatic conditions (Grubben and Denton, 2004). Similarly, in Ethiopia, the actual spacing, harvest maturity and harvesting interval or frequency of Swiss-chard is not yet known as there is no any substantial location specific research result. This experiment was therefore initiated to study and determine the optimum combined effects of intra-row spacing and harvesting interval of Swiss chard under Wolkite conditions.

\section{Materials and Methods}

\subsection{Description of the Study Area}

The experiment was conducted at Wolkite University, Ethiopia, within the field trial site of the Department of Horticulture. Wolkite University is located about $158 \mathrm{~km}$ southwest of Addis Ababa at $7.8-8.5^{\circ} \mathrm{N}$ latitude and $37.5-38.7^{\circ} \mathrm{E}$ longitude with an altitude range of $1300-1400 \mathrm{~m}$. The mean annual temperature ranges from $14^{\circ} \mathrm{C}$ to 
$24^{\circ} \mathrm{C}$ with an average of $20.5^{\circ} \mathrm{C}$. The average annual rainfall is $1294 \mathrm{~mm}$ and the soil type is by and large heavy vertisol.

\subsection{Experimental Design and Procedure}

The experiment was laid out in a Randomized Complete Block Design (RCBD) with a $3 * 3$ factorial arrangement in three replications. The two factors and their respective levels were:

(1) Factor 1: Intra- row spacing with three levels (i.e. $25 \mathrm{~cm}, 30 \mathrm{~cm}$ and $35 \mathrm{~cm}$ )

(2) Factor 2: Harvesting interval with three levels (6,12 and 18 days)

There were a total of nine treatment combinations and 27 experimental units. The plot size was $2.25 \mathrm{~m} 2$. The spacing between plots and blocks were $0.5 \mathrm{~m}$ and $1 \mathrm{~m}$ respectively. Seeds of the variety Ford Hook Giant were used, which were first raised under nursery condition and subsequently transplanted after 30 days of seeding. The inter-row spacing of the plants was maintained at the most commonly employed practice of $30 \mathrm{~cm}$.

\subsection{Data collected}

Data was collected periodically for the basic yield and yield components, i.e. yield (t/ha), average number of leaves/plant, average leaf width $(\mathrm{cm})$, average leaf length $(\mathrm{cm})$ and average plant height $(\mathrm{cm})$.

\subsection{Data Analysis}

The experimental data were analyzed through the Analysis of Variance (ANOVA) by using GLM procedure of SAS software version 9.2. The Least Significant Differences (LSD \%) test was used to determine the level of significance at $5 \%(\mathrm{P}<0.05)$.

\section{Results and Discussion}

\subsection{Effect on Yield (t/ha)}

As stated under Table 1 below, statistically significant difference $(\mathrm{p} \leq 0.05)$ was observed among the treatment combinations on their effect on the yield of Swiss chard. The highest yield (42.51 t/ha) was obtained from the treatment combination of $30 \mathrm{~cm}$ intra-row spacing and 18 days harvesting interval. Conversely, the lowest yield $(23.23 \mathrm{t} / \mathrm{ha})$ was harvested from the lowest intra-row spacing of $25 \mathrm{~cm}$ when combined with the lowest harvesting interval of six days.

This result of the experiment also concurs with previous findings of other researchers (Lopez et al. 2005, Delong et al., 2011, Amaglao et al., 2006, Aliyu et al., 2002 and Kolato et al., 2010) that excessive increase in the number of plant population of Swiss chard per unit area, as a result of the narrow spacing, reduced the production of leaf weight per plant, which subsequently decreased the yield. Concurrently, they also stated that leaf yield was reduced drastically with continuous harvesting or shorter harvesting interval. Besides, the right time of maturity for harvesting of the leaves was one of the major factors that determined the physicochemical compositional quality and antioxidant levels of Swiss-chard.

Table 1. Combined effect of intra-row spacing and harvesting interval on yield $(\mathrm{t} / \mathrm{ha})$ of Swiss chard

\begin{tabular}{|c|c|c|}
\hline No. & Treatment & Av. yield (t/ha) \\
\hline 1 & $25 \mathrm{~cm} \times 6$ days & $23.23^{\mathrm{bc}}$ \\
\hline 2 & $25 \mathrm{~cm} \times 12$ days & $31.12^{\mathrm{abc}}$ \\
\hline 3 & $25 \mathrm{~cm} \mathrm{x} 18$ days & $39.84^{\mathrm{ab}}$ \\
\hline 4 & $30 \mathrm{~cm} \times 6$ days & $25.61^{\mathrm{bc}}$ \\
\hline 5 & $30 \mathrm{~cm} \times 12$ days & $38.32^{\mathrm{ab}}$ \\
\hline 6 & $30 \mathrm{~cm} \mathrm{x} 18$ days & $37.13^{\mathrm{abc}}$ \\
\hline 7 & $35 \mathrm{~cm} \times 6$ days & $37.72^{\mathrm{abc}}$ \\
\hline 8 & $35 \mathrm{~cm} \mathrm{x} 12$ days & $36.95^{\mathrm{abc}}$ \\
\hline \multirow[t]{3}{*}{9} & $35 \mathrm{~cm} \mathrm{x} 18$ days & $42.51^{\mathrm{a}}$ \\
\hline & $\operatorname{LSD}(0.05)$ & 8.214 \\
\hline & CV $(\%)$ & 12.5 \\
\hline
\end{tabular}

\subsection{Effect on Leaf Number}

As depicted under Table 2 below, most of the treatment combinations showed statistically significant difference 
on their effect on leaf number of Swiss chard. While the highest average leaf number (8.17) was recorded from the treatment combinations of $35 \mathrm{~cm} \times 12$ days and $25 \mathrm{~cm} \times 18$ days, the lowest $(5.75)$ was recorded from the narrowest intra-row spacing of $25 \mathrm{~cm}$ and the shortest harvesting interval of 6 days. This result also agrees with the previous findings of Yemane et al. (2013) that the highest intra-row spacing of $10 \mathrm{~cm}$ was superior in its effect on plant height and leaf number per plant of onion. Similarly, Melak Agajie (2018) reported that the number of primary branches of chickpea was increased as the intra-row spacing increased and there was a progressive increase of the number of pods per plant as both the inter and intra-row spacing increased. He further stated that for all the inter-row spacing variables tested, the harvest index of chickpea was increased as the intrarow spacing increased.

Table 2. Combined effect of intra-row spacing and harvesting interval on leaf number of Swiss-Chard

\begin{tabular}{|c|c|c|}
\hline No. & Treatment & Av. leaf number/plant \\
\hline 1 & $25 \mathrm{~cm} \times 6$ days & $5.75^{\mathrm{b}}$ \\
\hline 2 & $25 \mathrm{~cm} \times 12$ days & $6.92^{\mathrm{ab}}$ \\
\hline 3 & $25 \mathrm{~cm} \times 18$ days & $7.17^{\mathrm{ab}}$ \\
\hline 4 & $30 \mathrm{~cm} \times 6$ days & $7.22^{\mathrm{ab}}$ \\
\hline 5 & $30 \mathrm{~cm} \times 12$ days & $7.22^{\mathrm{ab}}$ \\
\hline 6 & $30 \mathrm{~cm} \times 18$ days & $7.11^{\mathrm{ab}}$ \\
\hline 7 & $35 \mathrm{~cm} \times 6$ days & $7.00^{\mathrm{ab}}$ \\
\hline 8 & $35 \mathrm{~cm} \times 12$ days & $8.17^{\mathrm{a}}$ \\
\hline \multirow[t]{3}{*}{9} & $35 \mathrm{~cm} \times 18$ days & $8.17^{\mathrm{a}}$ \\
\hline & $\operatorname{LSD}(0.05)$ & 1.602 \\
\hline & CV $(\%)$ & 12.9 \\
\hline
\end{tabular}

\subsection{Effect on Plant Height (cm)}

As shown under Table 3 below, most of the treatment combinations, except $25 \mathrm{~cm} \times 6$ days and $35 \mathrm{~cm} \times 18$ days, showed statistically none significant difference on their effect on plant height of Swiss chard. Similarly, while the highest average plant height $(43.33 \mathrm{~cm})$ was recorded from the largest treatment combination of $35 \mathrm{~cm} \times 18$ days, the lowest $(31.33 \mathrm{~cm})$ was recorded from $25 \mathrm{~cm}$ x 6 days. This result also agrees with previous findings of Yemane et al. (2013) that the highest intra-row spacing of $10 \mathrm{~cm}$ was superior in its effect on plant height and leaf number per plant of onion.

Table 3. Combined effect of intra-row spacing and harvesting interval on plant height $(\mathrm{cm})$ of Swiss-Chard

\begin{tabular}{|c|c|c|}
\hline No. & Treatment & Av. plant height $(\mathrm{cm})$ \\
\hline $\begin{array}{l}1 \\
2\end{array}$ & $\begin{array}{l}25 \mathrm{~cm} \times 6 \text { days } \\
25 \mathrm{~cm} \times 12 \text { days }\end{array}$ & $\begin{array}{c}31.33^{\mathrm{c}} \\
35.58^{\mathrm{abc}}\end{array}$ \\
\hline 3 & $25 \mathrm{~cm} \mathrm{x} 18$ days & $41.25^{\mathrm{ab}}$ \\
\hline 4 & $30 \mathrm{~cm} \times 6$ days & $33.33^{b c}$ \\
\hline 5 & $30 \mathrm{~cm} \times 12$ days & $39.00^{\mathrm{abc}}$ \\
\hline 6 & $30 \mathrm{~cm} \mathrm{x} 18$ days & $38.00^{\mathrm{abc}}$ \\
\hline 7 & $35 \mathrm{~cm} \times 6$ days & $38.50^{\mathrm{abc}}$ \\
\hline 8 & $35 \mathrm{~cm} \times 12$ days & $36.67^{\mathrm{abc}}$ \\
\hline \multirow[t]{3}{*}{9} & $35 \mathrm{~cm} \mathrm{x} 18$ days & $43.33^{\mathrm{a}}$ \\
\hline & $\operatorname{LSD}(0.05)$ & 8.394 \\
\hline & CV $(\%)$ & 13.0 \\
\hline
\end{tabular}

Means indicated by the same letter are not significantly different at $5 \%$ level of significance $(P \leq 0.05)$, using Fishers' protected t-test. 


\subsection{Effect on Leaf Length (cm)}

Table 4 below shows that all the treatment combinations, other than $25 \mathrm{~cm} \times 6$ days and $35 \mathrm{~cm} \times 18$ days, showed statistically none significant difference on their effect on leaf length of Swiss chard. While the highest leaf length $(32 \mathrm{~cm})$ was obtained from the treatment combination of $35 \mathrm{~cm} \mathrm{x} 18$ days, the lowest $(24 \mathrm{~cm})$ was recorded from treatment combination $25 \mathrm{~cm} \times 6$ days.

Table 4. Combined effect of intra-row spacing and harvesting interval on leaf length $(\mathrm{cm})$ of Swiss chard

\begin{tabular}{|c|c|c|}
\hline No. & Treatment & Av. leaf length/plant (cm) \\
\hline 1 & $25 \mathrm{~cm} x 6$ days & $24.00^{\mathrm{b}}$ \\
\hline 2 & $25 \mathrm{~cm} \times 12$ days & $25.42^{\mathrm{ab}}$ \\
\hline 3 & $25 \mathrm{~cm} \mathrm{x} 18$ days & $29.92^{\mathrm{ab}}$ \\
\hline 4 & $30 \mathrm{~cm} \times 6$ days & $26.33^{\mathrm{ab}}$ \\
\hline 5 & $30 \mathrm{~cm} \times 12$ days & $27.33^{\mathrm{ab}}$ \\
\hline 6 & $30 \mathrm{~cm} \times 18$ days & $29.33^{\mathrm{ab}}$ \\
\hline 7 & $35 \mathrm{~cm} \times 6$ days & $29.17^{\mathrm{ab}}$ \\
\hline 8 & $35 \mathrm{~cm} \mathrm{x} 12$ days & $29.00^{\mathrm{ab}}$ \\
\hline \multirow[t]{3}{*}{9} & $35 \mathrm{~cm} \mathrm{x} 18$ days & $32.00^{\mathrm{a}}$ \\
\hline & $\operatorname{LSD}(0.05)$ & 7.556 \\
\hline & $\mathrm{CV}(\%)$ & 15.6 \\
\hline
\end{tabular}

\subsection{Effect on Leaf Width (cm)}

Unlike in the other parameters evaluated, all the treatment combinations showed statistically none significant difference on their effect on leaf width of Swiss chard (Table 5). However, the highest leaf width $(17.67 \mathrm{~cm})$ was again obtained from the combined effect of $35 \mathrm{~cm}$ intra-row spacing and 18 days harvesting interval while the least $(14.08 \mathrm{~cm})$ was recorded from the lowest treatment combination of $25 \mathrm{~cm} \times 6$ days.

Table 5. Combined effect of intra-row spacing and harvesting interval on leaf width $(\mathrm{cm})$ of Swiss-Chard

\begin{tabular}{|c|c|c|}
\hline No. & Treatment & Av. leaf width/plant $(\mathrm{cm})$ \\
\hline 1 & $25 \mathrm{~cm} \times 6$ days & $14.08^{\mathrm{a}}$ \\
\hline 2 & $25 \mathrm{~cm} \times 12$ days & $14.75^{\mathrm{a}}$ \\
\hline 3 & $25 \mathrm{~cm} \mathrm{x} 18$ days & $16.33^{\mathrm{a}}$ \\
\hline 4 & $30 \mathrm{~cm} \times 6$ days & $15.44^{\mathrm{a}}$ \\
\hline 5 & $30 \mathrm{~cm} \times 12$ days & $15.78^{\mathrm{a}}$ \\
\hline 6 & $30 \mathrm{~cm} \mathrm{x} 18$ days & $15.89^{\mathrm{a}}$ \\
\hline 7 & $35 \mathrm{~cm} \times 6$ days & $14.67^{\mathrm{a}}$ \\
\hline 8 & $35 \mathrm{~cm} \mathrm{x} 12$ days & $16.00 \mathrm{a}$ \\
\hline \multirow[t]{3}{*}{9} & $35 \mathrm{~cm} \mathrm{x} 18$ days & $17.67^{\mathrm{a}}$ \\
\hline & $\operatorname{LSD}(0.05)$ & 4.465 \\
\hline & $\mathrm{CV}(\%)$ & 16.5 \\
\hline
\end{tabular}

Means indicated by the same letter are not significantly different at $5 \%$ level of significance $(P \leq 0.05)$, using Fishers' protected t-test.

\section{Concluding Remarks}

All the treatment combinations, other than $25 \mathrm{~cm} \times 6$ days and $35 \mathrm{~cm} \times 18$ days, showed statistically none significant difference on their effect on leaf length of Swiss chard.

While the highest average leaf number (8.17) was obtained from the treatment combinations of $35 \mathrm{~cm} \times 12$ days and $25 \mathrm{~cm} \times 18$ days, the lowest (5.75) was recorded from $25 \mathrm{~cm} \times 6$ days.

All the treatment combinations showed statistically none significant difference on their effect on leaf width of Swiss chard. However, the highest average leaf width $(17.67 \mathrm{~cm})$ was recorded from the combined effect of 35 $\mathrm{cm}$ intra-row spacing and 12 days harvest interval. 
While the highest average plant height $(43.33 \mathrm{~cm})$ was obtained from the treatment combination of $35 \mathrm{~cm} x$ 18 days, the lowest $(31.33 \mathrm{~cm})$ was recorded from $25 \mathrm{~cm} \times 6$ days.

Therefore, since the highest yield $(42.51 \mathrm{t} / \mathrm{ha})$ and yield components $(32.0 \mathrm{~cm}$ average leaf length, 8.17 average leaf number, $17.67 \mathrm{~cm}$ average leaf width and $43.33 \mathrm{~cm}$ average plant height) were obtained from the combined effect of $35 \mathrm{~cm}$ intra-row spacing and 18 days harvesting interval, Swiss chard growers under conditions similar to Wolkite are recommended to use the same treatment combination.

\section{Acknowledgements}

The authors are thankful for the financial support of Wolkite University for the implementation of the experiment.

\section{References}

Aliyu, L.Yanaya,R..Arunah M. and Haruna.I. 2002. Response at two chive paper varieties to harvesting frequency. Horti Isi., Hamada Bello University Zaire

Amaglao, N., Timpo, M..Ellis W. and Bennett.R., 2006. Effect of spacing and harvesting frequency on growth and yield of Moringa as leaf vegetables, Horticulture facility of Agriculture . Kumasi.

Delong, E ., 2011. Conedlines for harvesting vegetable.Biotechnology and natural hazard, UK.

Faber, M., Jaarsveld, P. J. and Laubscher, R. 2007. The Contribution of Dark-Green Leafy Vegetables to Total Micro-Nutrient Intake of Two- to Five-Year-Old Children in a Rural Setting. Water SA. 33: 407-412.

Gao, Z. J., Han, X. H. and Xiao, X. G. 2009. Purification and Characterization of Polyphenol Oxidase from Red Swiss Chard (Beta vulgaris Subspecies Cicla) Leaves. Food Chem., 117: 342-348.

George,M. 2015. What new and beneficial about Swiss-Chard .World food science.

Grubben, G. and Denton, 2004. Plant Resources of Tropical Africa. Vegtable Prota Foundation Wageningen Netherland/ Backhuys Puplisher, Leiden.

Jenet, B. 2008. Scheduling vegetable plantings for continuous harvest national sustainable agriculture information service. www.attra.ncotoorg.

Kalato, E. and CzermiakK., Aoran S . 2010. The effect N fertilizer on yield and nutritional value of swisschard, Environmental science and life science, pp31-37

Lopez, B. 2005 .Competition, growth and yield of faba bean. European journal of agronomy 23; 359-378.

Melak Agajie. 2018. Effect of Spacing on Yield Components and Yield of Chickpea (Cicer arietinum L.) at Assosa, Western Ethiopia. Journal of Agriculture, Forestry and Fisheries: 7(2): 39-51. Science Publishing Group.

Pyo, Y., T. Lee, L. Logendra, and R. T. Rosen. 2004. Antioxidant Activity and Phenolic Compounds of Swiss Chard (Beta vulgaris Subspecies Cycla) Extracts. Food Chem., 85: 19-26.

Seid ,H., Merema K. and Mestawat W. ,2013. Effect of intra row spacing on growth and development of tomato. .InstiHorti. , Wollo. Ethiopia..Shun M., 2000. Efect of plant spacing on fruit yield in okra, ,Agricaltural Science, Digest Kamal .40-42PP.

Smith, D .Beharee V. Hughes G. 2001 .The effects of composis produced by a simple composting procedure on the yields of Swiss chard and common bean. Scientia Hort .91:393-106.

Swiader, J.M., Ware, G.W., \& Mccollum, J.P. 1992. Producing vegetable crops. Danville, Illinois, USA: Interstate. Pubblishers Inc.

van Wyk, B. E. 2005. Food Plants of the World, Identification, Culinary Uses and Nutritional Value. $1^{\text {st }}$ Edition, Briza Publication, Pretoria, South Africa.

Yemane Kahsay, Derbew Belew and Fetien Abay. 2014. Effects of Intra-Row Spacing on Plant Growth and Yield of Onion Varieties (Allium cepa. L) at Aksum, Northern Ethiopia. African Journal of Agricultural Research. Vol. 9 (10): pp 931-940 